\title{
Aportaciones al estudio de la gestualidad en la iconografía románica hispana
}

\author{
Alicia Miguélez Cavero
}

\section{OpenEdition}

\section{Journals}

\section{Edición electrónica}

URL: http://journals.openedition.org/medievalista/474

DOI: 10.4000/medievalista.474

ISSN: 1646-740X

\section{Editor}

Instituto de Estudos Medievais - FCSH-UNL

Referencia electrónica

Alicia Miguélez Cavero, « Aportaciones al estudio de la gestualidad en la iconografía románica hispana », Medievalista [En línea], 8 | 2010, Puesto en línea el 01 julio 2010, consultado el 01 mayo 2019. URL http://journals.openedition.org/medievalista/474 ; DOI : 10.4000/medievalista.474

(C) IEM 
Titulo: Aportaciones al estudio de la gestualidad en la iconografía románica hispana.

Autor(es): Alicia Miguélez Cavero

Enquadramento Institucional:

Contacto: alimiguelez@gmail.com

Fonte: Medievalista [Em linha]. №8, (Julho 2010). Direc. José Mattoso. Lisboa: IEM.

Disponível em: http://www2.fcsh.unl.pt/iem/medievalista/

ISSN: 1646-740X

\section{Resumo}

O objectivo deste trabalho é analisar uma série de aspectos gerais relacionados com as representações gráficas de gestos na iconografia românica da Península Ibérica. Esta contribuição é baseada na configuração prévia de um corpus gestual, formado por atitudes, gestos e posturas representados na Arte Românica dos reinos hispânicos. Os aspectos em estudo centram-se sobretudo na forma, significado e origem dos gestos.

\section{Abstract}

The aim of this paper is to set a series of general aspects related to the graphic representations of gestures in the Romanesque iconography of the Iberian Peninsula. This approach is based on the prior configuration of a gestural corpus, formed by attitudes, gestures and postures portrayed in the Romanesque Art of the Spanish kingdoms. The aspects dealt with affect the form, meaning and origin of gestures mainly. 


\title{
Aportaciones al estudio de la gestualidad en la iconografía románica hispana*
}

\author{
Alicia Miguélez Cavero
}

El objetivo de este trabajo es plantear una serie de aspectos de carácter general en relación con la plasmación de los gestos en la iconografía románica hispana. Dichos planteamientos se basan en la previa configuración de un corpus gestual de actitudes, gestos y posturas presentes en la iconografía románica de los reinos hispanos ${ }^{1}$.

El sistema metodológico que hemos utilizado para realizar el mencionado catálogo gestual se ajusta a tres criterios de clasificación: la forma, el significado y el origen. En primer lugar, hemos llevado a cabo una primera clasificación de los gestos según su forma. Hemos hecho una distinción entre gestos, posturas y maneras libres, es decir, manifestaciones gestuales que implican a un único elemento del cuerpo humano; y los que son trabados, ya que implican el contacto o interacción de dos o más elementos corporales. Estos últimos los hemos dividido, a su vez, en autoadaptadores, ya que aluden al contacto de dos partes de un mismo cuerpo, alteradaptadores, en los que intervienen al menos dos personas, y objetoadaptadores, que remiten a una interacción con los objetos ${ }^{2}$.

\footnotetext{
*El presente trabajo es derivación y profundización de la Tesis Doctoral que hemos realizado sobre el tema "Gesto y gestualidad en el arte románico de los reinos hispanos: lectura y valoración iconográfica", dirigida por la Prof. Dra. Etelvina Fernández González y defendida en la Universidad de León el 12 de noviembre de 2009. El tribunal que juzgó el trabajo estuvo formado por los doctores: M. Valdés Fernández, I. B. Bango Torviso, M. C. Muñoz Párraga, M. A. Miranda y M. C. Cosmen Alonso, y recibió la calificación de Sobresaliente cum Laude por unanimidad y Mención Europea. Posteriormente, dicha investigación doctoral ha sido galardonada con el Premio de Tesis Doctorales que anualmente concede la asociación Círculo Románico, gracias al cual será publicada en toda su extensión próximamente.

${ }^{1}$ La acotación espacio-temporal que nos hemos marcado para dicho corpus es la Península Ibérica durante los siglos del románico. El primero de los límites es de carácter geográfico, es decir, nos ocuparemos de las creaciones artísticas realizadas en los territorios cristianos de los reinos hispanos de la Península Ibérica. En segundo lugar, desde el punto de vista temporal, nos desenvolvemos, principalmente, en un arco que abarca desde aproximadamente el año mil hasta los inicios del gótico en el siglo XIII.

2 Este sistema metodológico está basado en los estudios sobre gestualidad realizados en disciplinas relacionadas con la lingüística, entre las que cabe destacar la semiótica y la kinésica. Consideramos de gran interés para nuestro trabajo los estudios realizados por F. Poyatos. Este investigador ha distinguido entre varias categorías kinésicas: por un lado los gestos, a los que define como "movimientos conscientes
} 
Los diferentes gestos analizados han sido, asimismo, organizados siguiendo un criterio vertical. Se ha dividido el cuerpo en tres niveles: superior, en relación con la cabeza; intermedio, tronco y extremidades superiores; e inferior, las extremidades inferiores ${ }^{3}$. A partir de esta clasificación formal, hemos llevado a cabo una identificación de los temas iconográficos, tanto de carácter sacro como profano, en los que estos gestos fueron utilizados.

Tras el análisis de carácter formal e iconográfico, cada una de las variedades gestuales ha sido analizada en función del significado o los significados que pudieron adquirir en época románica, así como un intento de aproximación a su origen. Todo ello nos lleva a plantear una serie de aspectos que, en ningún caso consideramos definitivos sino que esperamos seguir analizando en estudios posteriores.

\section{Aspectos de carácter general}

La primera de las consideraciones importantes que se desprenden del corpus gestual que hemos realizado es la existencia de un lenguaje gestual plástico de enorme riqueza en la iconografía románica en general y, en la de los reinos hispanos, en particular. Aunque siempre se ha estimado que el arte gótico es el paradigma de la expresión de sentimientos y emociones dentro de la mentalidad y la cultura medievales, lo cierto es

o inconscientes principalmente con la cabeza, la cara sólo (incluyendo la mirada) o las extremidades, dependientes o independientes del lenguaje verbal-paralingüístico, alternando con él o simultáneamente y que constituyen una forma principal de comunicación: sonrisas, guiños, una mirada de reojo etc". En segundo lugar estarían las maneras, que según F. Poyatos son "más o menos conscientes y más o menos dinámicas, principalmente aprendidas y ritualizadas socialmente según el contexto situacional, alternando también con las palabras o simultáneas a ellas". Por último, las posturas son "estáticas (pues lo que puede hacerlas "moverse" será una manera o un modo) e igualmente conscientes o inconscientes, también ritualizadas y, como en el caso de las maneras, menos utilizadas como formas de un repertorio comunicativo, aunque, a semejanza de gestos y maneras, comunican de todas formas el sexo, la posición social, el origen cultural, el estado de ánimo etc". Sobre la definición de gesto, manera y postura, así como su distinción entre libre y trabado véase: F. POYATOS, La comunicación no verbal, 3 vols., Madrid, 1981, especialmente vol. II..., capítulo 5: La Kinésica: gestos, maneras y posturas, e ID., "Gesture Inventories: Fieldwork Methodology and Problems", Nonverbal Communication, Interaction and Gesture. Selections from Semiotics (A. Kendon ed.), The Hague, 1981, p. 374.

${ }^{3}$ J. E. Finol sugiere que el cuerpo humano puede dividirse siguiendo tres criterios diferentes. El primero de ellos sería el vertical, según el cual en el cuerpo podemos distinguir los niveles superior, intermedio e inferior; en segundo lugar estaría el horizontal, de acuerdo con el cual el cuerpo quedaría segmentado en lado izquierdo, centro y lado derecho; por último, existiría un tercer criterio, que dividiría el cuerpo en frontal y posterior. Véase: J. E. FINOL, "Cuerpo y rito: la estructura del gesto en ceremonias públicas", Los Gestos. Sentidos y prácticas, DeSignis, 3 (2002), pp. 81-90. En nuestro caso, hemos optado por seguir el criterio vertical. 
que el arte románico supone un primer estadio en el surgimiento de esa expresividad, evolucionando posteriormente hasta llegar a la gran eclosión naturalista gótica.

Además, este rico lenguaje gestual cumple una serie de funciones básicas en el contexto del arte románico y la sociedad que lo creó. En la Edad Media, la visión cristiana que el hombre medieval tenía de su cuerpo influyó sobremanera en la propia consideración de los gestos. Por un lado, el cuerpo era sinónimo de pecado y por ello hacía más difícil la salvación humana. En este sentido, los gestos, como prolongación del cuerpo, tenían un valor claramente negativo. Por otro lado, el cuerpo humano podía también ser símbolo de virtud, de manera que aquellos gestos relacionados con esta última tenían un valor positivo y contribuían a conseguir esa salvación tan deseada por el hombre medieval ${ }^{4}$.

Por ello, no es extraño que posturas, actitudes y conductas gestuales pasaran a desempeñar también un papel decisivo en las creaciones artísticas. En la mayoría de las ocasiones, las representaciones plásticas ofrecen gestos muy similares a los que se adoptaban en la vida real, de manera que eran fácilmente reconocibles y descifrables por los ojos del hombre medieval.

\section{Forma e iconografía de los gestos}

En segundo lugar, en lo que respecta al análisis formal e iconográfico que hemos llevado a cabo, podemos aseverar que ese lenguaje gestual tan rico lo hallamos en el ámbito de la creación tanto de imágenes sacras como profanas. Las mismas actitudes, los gestos, las posturas y las conductas fueron utilizados por los artistas para plasmar escenas religiosas y juglarescas. Es el caso, por ejemplo, de la representación de

\footnotetext{
${ }^{4}$ Debido a esta variedad de significados, en época medieval existían dos acepciones diferentes que definían cada uno de estos dos conceptos. En primer lugar, el término gestus se asociaba con la concepción positiva de los gestos. A partir de su forma diminutiva, gesticulus, encontramos otros dos términos, gesticularius y, sobre todo, gesticulatio, que eran utilizados en los contextos en los que los gestos adquirían una connotación negativa o peyorativa. Así, gesticulatio es el término que se empleaba para describir las actividades y conductas gestuales realizadas por los mimos, los pantomimos, los histriones, es decir, las clases más bajas de la sociedad medieval en las que, según las promulgaciones de la Iglesia, se encarnan el pecado, los vicios y los instintos más básicos del ser humano. Sobre estos aspectos véase: V. DÍAZ-CORRALEJO, Los gestos en la literatura medieval, Madrid, 2004, p. 15; J. LE GOFF y N. TRUONG, Une histoire du corps au Moyen Âge, París, 2003, p. 161; J.-C. SCHMITT, "Gestus-gesticulatio: contribution à l' étude du vocabulaire latin médiéval des gestes", La lexicographie du latin médiéval et ses rapports avec les recherches actuelles sur la civilisation du Moyen Âge, Paris, CNRS, 1981, pp. 377-390 ; ID., La raison des gestes dans l'Occident medieval, Paris, 2003, pp. 34-35.
} 
personajes posicionados con la cabeza hacia abajo y las piernas flexionadas, imagen plástica de juglares y mimos. La hallamos en la plasmación de pasajes del texto bíblico, como es el caso de la figuración del pasaje veterotestamentario de la adoración de la estatua de Nabucodonosor en la Biblia de Roda ${ }^{5}$, así como en la decoración escultórica de multitud de canecillos en el exterior de las iglesias románicas.

En este sentido, sin embargo, debemos hacer una puntualización respecto a la iconografía bíblica. Los gestos que encontramos en las imágenes que reproducen pasajes del Antiguo Testamento suelen ser mucho más expresivos e incluso violentos que las actitudes mostradas por los protagonistas de escenas neotestamentarias, donde la expresión de sentimientos y emociones es más contenida. Este hecho va parejo con los propios textos, ya que las descripciones veterotestamentarias son siempre mucho más vívidas y vehementes que en el caso del Nuevo Testamento.

Por lo que se refiere a las particularidades gestuales que hemos encontrado en la iconografía románica peninsular hispana respecto al grueso del románico europeo, el primer aspecto a señalar es que, de manera general, el lenguaje gestual presente en la plástica de los reinos hispánicos responde, perfectamente, a los parámetros de la estética románica de otras regiones. Los gestos utilizados por artistas de otras regiones los hallamos, de igual manera, en las manifestaciones plásticas de los reinos hispanos.

Aun así, podemos precisar una particularidad importante: se trata del excepcional desarrollo que tuvieron en la Península Ibérica las escenas de luto, en la iconografía funeraria. Al contrario de lo que sucede en otros territorios europeos, la plástica románica hispana dio rienda suelta a la plasmación gráfica de una serie de gestos rituales entre los que podemos señalar actitudes de autolesión como mesarse los cabellos o la barba, y otras más contenidas, como llevarse una mano a la mejilla y cruzar las manos ante el vientre. Todas ellas son, además, comportamientos que podemos considerar como una traslación al campo artístico de prácticas y rituales llevados a cabo en la sociedad de este momento y que hemos contrastado con fuentes de carácter documental o literario ${ }^{6}$.

\footnotetext{
${ }^{5}$ Biblia de Roda, París, Bibliothèque nationale de France, latin 6, III, f. 64v.

${ }^{6}$ En la Edad Media ibérica, los cortejos fúnebres estaban presididos por un coro de plorantes y plañideras, que iban acompañando al féretro y realizaban gestos violentos de dolor, como los que vemos en la iconografía, llegando en algunos casos a la autolesión. Sin embargo, no se trata de prácticas que tuvieron
} 
En la iconografía románica hispana, este tipo de escenas tuvieron un gran desarrollo en los programas iconográficos de los sarcófagos suponiendo el origen de lo que después sería su excepcional desarrollo en el arte gótico, cuando estas imágenes alcanzaron su máxima expresión, para después decaer en los años finales del período medieval. Destaquemos varios ejemplos realmente expresivos:

En el sepulcro de Blanca de Navarra, conservado en el monasterio de Santa María la Real de Nájera, la escena del duelo por este personaje de la realeza castellana se encuentra en uno de los frentes del sarcófago, donde se esculpieron dos grupos de dolientes, situados a ambos lados del lecho mortuorio. A la derecha está el rey Sancho, que inclina la cabeza, como desmayado, y es sostenido por otros dos personajes. A la izquierda, dos figuras femeninas sostienen a otra que se lleva la mano a la mejilla, con la cabeza inclinada, como el rey, mientras otra se mesa los cabellos, y, en el extremo izquierdo, otra cruza las manos ante el cuerpo ${ }^{7}$.

Algo posterior es la escena de luto representada en el sarcófago de Egas Moniz, conservado en la iglesia lusa de San Salvador de Paço de Sousa. Esta escena, hoy en el

lugar únicamente en la Edad Media, sino que podemos enmarcarlas dentro del contexto de la cultura mediterránea. Aparecen en la mayoría de las culturas del mundo antiguo: Egipto, Grecia y Roma, siendo posteriormente heredadas por la tradición cristiana, aun en contra de la opinión de la mayoría de los escritores y padres de la Iglesia, que no las consideraban dignas. Ya en la Alta Edad Media, la Iglesia mostró su disconformidad ante la ostentación del dolor mediante gestos exagerados, ya que iba en contra de la creencia en la resurrección. Por ello, en la mayor parte de los territorios europeos, este tipo de prácticas y rituales fueron canalizándose y reduciéndose a lo largo del período medieval. Sin embargo, en el caso de la Península Ibérica, se suceden continuamente los documentos que condenan las actitudes más exageradas, lo que indica que esta costumbre no había desaparecido. Esta situación llegó a su punto culminante en el siglo XIV. A partir de entonces, las manifestaciones de dolor empezaron ya a ser controladas por los poderes municipales y eclesiásticos, de manera que se trataron de reprimir los gestos más excesivos. Los testamentos bajomedievales, en los que se relatan detalladamente los pasos a seguir a la muerte de un personaje, ilustran este cambio, operado a partir del s. XV, respecto a momentos anteriores. Sobre estos aspectos, véase: C. FRUGONI, "La grammatica dei gesti. Qualche riflessione", Atti delle LII Settimane di Studio della Fondazione Centro Italiano di Studi sull’alto Medioevo: Comunicare e significare nell'alto Medioevo, 15-20 aprile 2004, vol. II, Spoleto, 2005, p. 923; A. GUIANCE, Los discursos sobre la muerte en la Castilla Medieval (siglos VII-XV), Valladolid, 1998, pp. 42-48; M. L. RODRIGO ESTEVAN, Testamentos medievales aragoneses. Ritos y actitudes ante la muerte (siglo XV), Zaragoza, 2002, pp. 99- 111; E. VALDEZ DEL ÁLAMO, "Lament for a lost Queen: the sarcophagus of Doña Blanca in Nájera", Memory and the Medieval Tomb, edited by Elizabeth Valdez del Álamo with Carol Stamatis Pendergast, Cambridge, 2000, pp. 48 y 52.

${ }^{7}$ Sobre esta representación, véase: R. SÁNCHEZ AMEIJEIRAS, "Ecos de la Chanson de Roland en la iconografía del sepulcro de doña Blanca en Santa María la Real de Nájera", Lecturas de Historia del Arte, 2 (1990), pp. 206-214; S. SILVA y VERÁSTEGUI, "La escultura funeraria en el románico español", Hispania cristiana: Estudios en honor del prof. D. José Orlandis Rovira en su septuagésimo aniversario, Pamplona, 1988, pp. 323-350, especialmente, pp. 337-338; VALDEZ DEL ÁLAMO, Op. cit., pp. 43-79. 
frente de los pies del sepulcro, nos muestra al difunto en su lecho, rodeado por varias figuras que se tiran de los cabellos en señal de dolor y sufrimiento ${ }^{8}$.

En tercer lugar, haremos alusión al sepulcro identificado como el del infante Sancho o la infanta Leonor en el panteón del monasterio de Las Huelgas Reales de Burgos. En el centro del lado frontal de esta cista y cobijada bajo una triple arquería, se desarrolla una escena de elevatio animae (fig. 1). El difunto se encuentra recostado en el lecho fúnebre, al tiempo que dos ángeles elevan su alma hacia el cielo. A ambos lados del lecho se hallan dos personajes que realizan gestos violentos de dolor: el personaje de la izquierda, femenino, se mesa los largos cabellos al tiempo que el de la derecha, masculino, se lacera las mejillas. En la cabecera del sepulcro se labraron, como en el frente, una serie de personajes bajo arcos de medio punto, que constituyen la continuación de la escena del cortejo. Se trata de cuatro personajes laicos que adoptan actitudes más contenidas que las de los dos personajes que acabamos de describir. La figura del extremo izquierdo, masculina, cruza las manos ante el pecho; la que está a su lado, femenina y con la cabeza velada, junta sus manos a la altura del vientre. El tercer personaje mantiene su mano izquierda ante el vientre, como la figura anterior, pero alza la derecha para sujetar el fiador de su capa. Por último, el personaje situado en el extremo de la derecha inclina la cabeza y apoya la mejilla en su mano, al tiempo que la otra mano se apoya en un bastón ${ }^{9}$.

\footnotetext{
${ }^{8}$ Sobre este sepulcro, véase C. A. FERREIRA DE ALMEIDA, História da arte em Portugal. O Românico, Lisboa, 2001, pp. 165-6.

${ }^{9}$ Sobre esta pieza y la identificación del personaje para el que fue realizado, véase: R. DEL ARCO, Sepulcros de la Casa Real de Castilla, Madrid, 1954, pp. 87-98; I. BANGO TORVISO, "El ámbito de la muerte", Monjes y Monasterios. El Císter en el Medievo de Castilla y León, Valladolid, 1998, p. 321; M. J. GÓMEZ BÁRCENA, Escultura gótica funeraria en Burgos, Burgos, 1988, pp. 189-190; M. GÓMEZMORENO, El Panteón de Las Huelgas de Burgos, Madrid, 1946, p. 9; J. L. HERNANDO GARRIDO, "Santa María la Real de Las Huelgas", Enciclopedia del Románico en Castilla y León. Burgos. Volumen II, Aguilar de Campoo, 2002, p. 800; M. J. HERRERO SANZ, "Los sepulcros del Panteón Real de Las Huelgas", Reales Sitios, XXVIII (1990), no 105, pp. 21-30; J. DEL HOYO, "El epitafio versificado atribuido a la infanta Leonor", Actas del II Congreso Internacional de Epigrafía Medieval, 11-15 de septiembre de 2006 (en prensa); A. MIGUÉLEZ CAVERO, "Texto, imagen y música: el dolor ante la muerte del infante don Sancho en el Panteón Real de Las Huelgas", II Coloquio Internacional de Epigrafía Medieval, León 11-15 de septiembre de 2006 (en prensa); J. PÉREZ CARMONA, Arquitectura y escultura románicas en la provincia de Burgos, Burgos, 1974, pp. 221-222.
} 


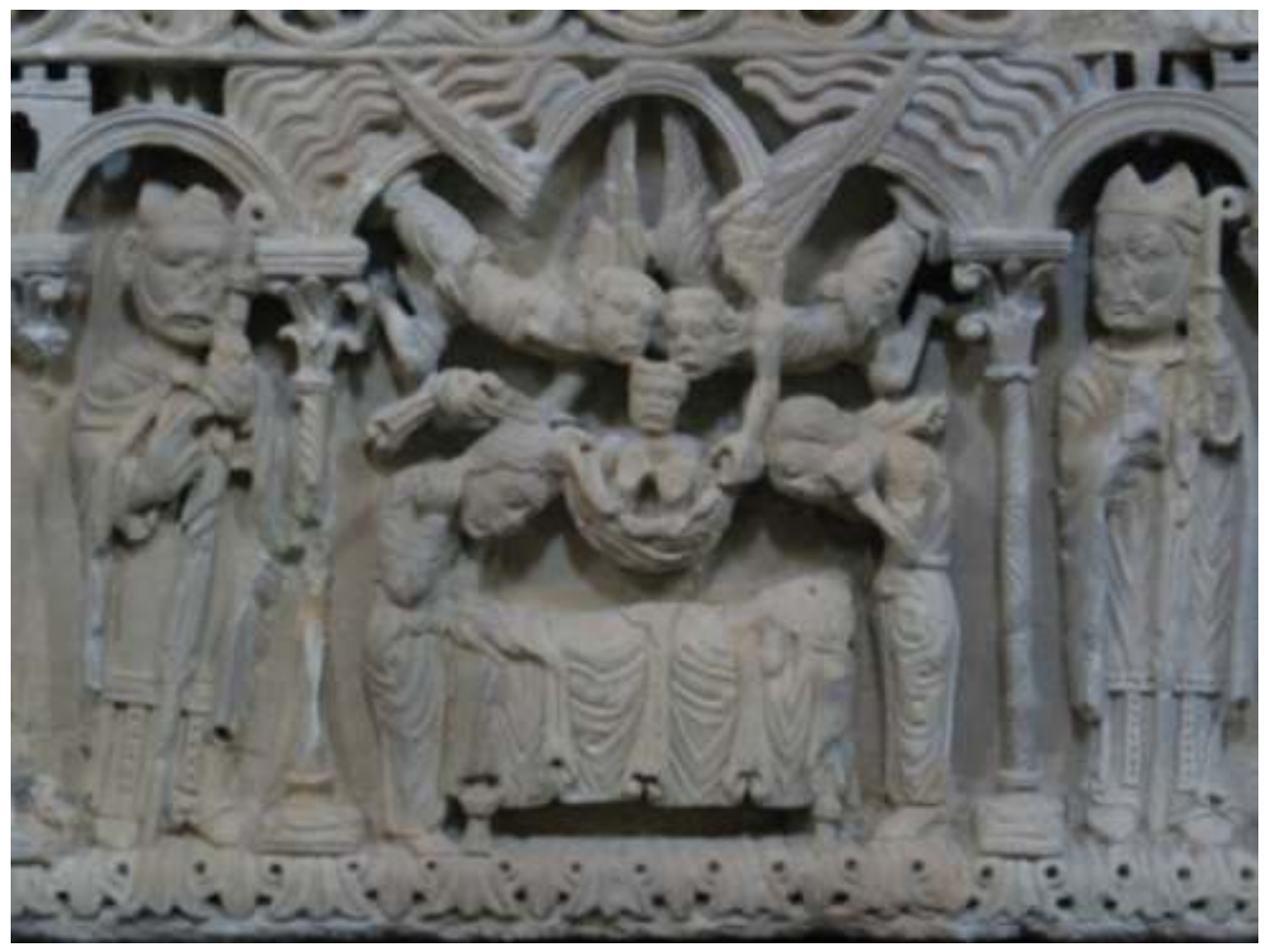

Fig. 1 Escena de Elevatio Animae

Sepulcro del infante don Sancho o de doña Leonor

Panteón Real de Las Huelgas

Burgos

\section{El significado de los gestos}

El tercero de los aspectos importantes en cuanto al análisis de los gestos en la iconografía románica hispana, está en relación con su significado. Podemos asegurar que todas las conductas representadas en el arte románico tienen un carácter primario, según la clasificación de comportamientos gestuales realizada por el antropólogo Desmond Morris ${ }^{10}$. Es decir, todos los gestos son incluidos en la imagen medieval con

10 D. Morris distingue, a este respecto, entre gestos primarios, es decir aquellos que realizamos conscientes de que queremos emitir un mensaje, y gestos secundarios. Estos últimos son realizados de manera casual, son acciones de carácter mecánico, como un estornudo, pero con las que, según este autor, también emitimos mensajes. Sin embargo, hay otros autores, como A. Kendon, que no consideran estas expresiones mecánicas como gestos. Para este último autor, el hecho de que alguien se ría de manera espontánea al escuchar algo divertido no podría ser considerado como gesto. Establece una gran diferencia entre los gestos convencionales, las gesticulaciones y las señales por un lado, y las actitudes, posturas, conductas autoadaptadoras y manipulación de objetos incidentales por otro. No obstante, admite que es muy difícil delimitar la línea que separa lo que es gesto de lo que no lo es. Sobre estos aspectos, 
un propósito definido, para emitir un mensaje determinado. No hallamos, por tanto, gestos secundarios ni acciones mecánicas o espontáneas.

En cuanto al propio significado de las posturas, existen, fundamentalmente, dos tipos de actitudes: por un lado, aquellas conductas que conllevan un solo significado; y por otro, las que acogen varios sentidos.

\section{Conductas monosemánticas}

En cuanto a las conductas monosemánticas, éstas son susceptibles de ser utilizadas en diversos contextos, situaciones, escenas y temas iconográficos y, además, ser adoptados por diversos personajes. Sin embargo, mantienen siempre una misma carga semántica.

Es el caso, por ejemplo, de la postración ${ }^{11}$. En relación con la plasmación gráfica del texto bíblico, hay varios pasajes en los que esta conducta gestual cobra importancia: la Epifanía, la Última Cena, el Noli me Tangere o la Resurrección de Lázaro, etc. Además, en el caso del arte hispano, es imprescindible citar la presencia de esta actitud en imágenes que ilustran diversos pasajes del Apocalipsis en los Beatos, por ejemplo la comisión del escrito o la adoración de la muchedumbre ante el trono. Por otro lado, el gesto de postrarse ante la figura de Dios Padre o de Cristo es uno de los más comunes en todo el Occidente medieval. Emperadores, reyes, obispos, clérigos, hombres del común... todos ellos pueden ser representados en esta actitud. Es altamente representativa, en este sentido, la imagen de los soberanos Fernando I y Sancha en las pinturas del panteón de los reyes de la Colegiata de San Isidoro de León, que se postran ante la figura de Cristo crucificado (fig. 2). En tercer lugar, podemos establecer un tercer grupo de figuras que adoptan esta postura y del que encontramos frecuentes ejemplos en el románico hispano. Se trata de la representación de condenados y penitentes. Todos ellos se arrodillan a la vez que levantan las manos y, muchos de ellos juntan también las manos. Por último, señalemos también la presencia de esta actitud en

véase: A. KENDON, "Gesture”, Annual Review of Anthropology, 26 (1997), pp. 109-128, especialmente pp. 109-110; D. MORRIS, Manwatching A Field Guide to Human Behavior, Nueva York, 1977, p. 24.

${ }_{11}$ Al mencionar el término postración, nos referimos a varias posturas: en primer lugar, el gesto de arrodillarse, es decir, de apoyar las dos rodillas juntas en el suelo, manteniendo el torso erguido o ligeramente inclinado. En segundo lugar, el de tumbarse en el suelo, apoyando las rodillas o con las extremidades inferiores completamente estiradas. 
escenas que plasman pasajes hagiográficos, en los que diversos personajes se postran ante las figuras de santos que llevan a cabo obras milagrosas.

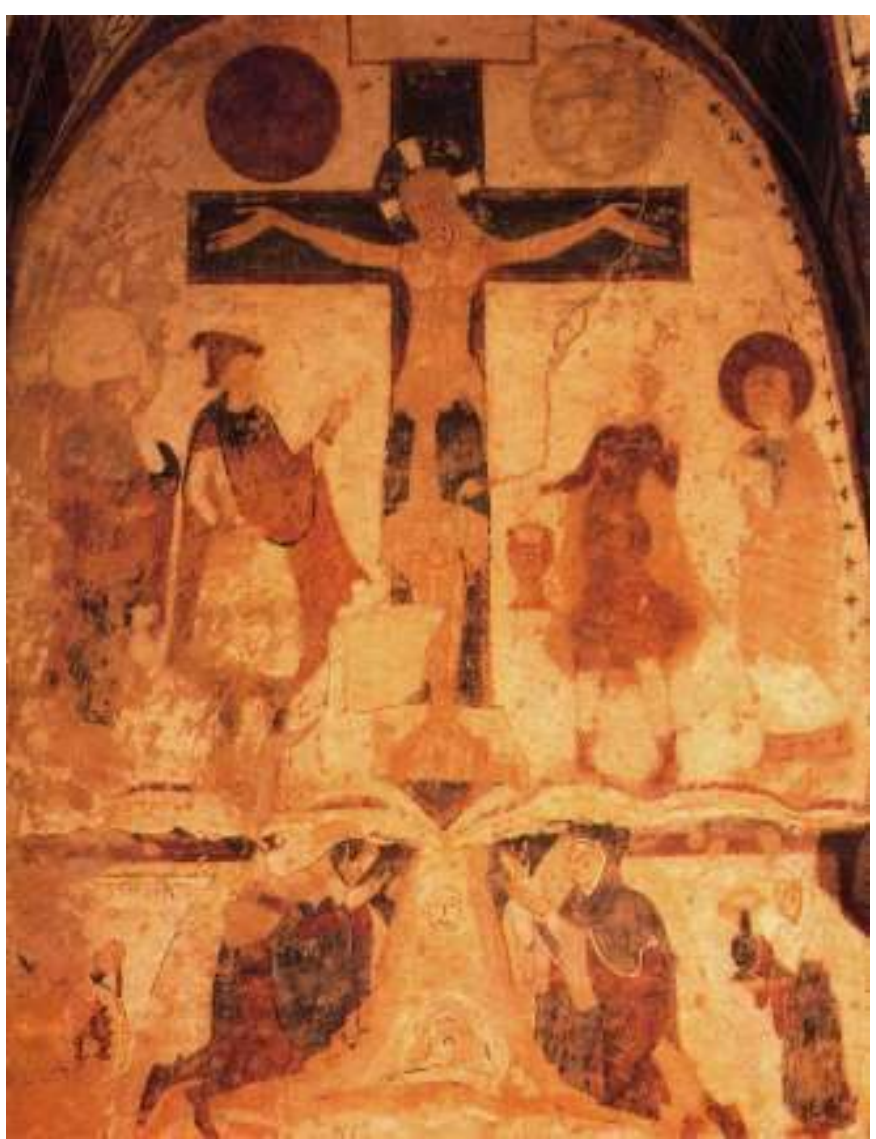

Fig. 2 Escena de la Crucifixión

Pinturas murales

Panteón Real de San Isidoro

León

Como vemos, por tanto, nos encontramos ante un gesto utilizado por los artistas en multitud de contextos, escenas y temas iconográficos. Pero se trata de una conducta gestual que transmite siempre una carga semántica muy similar. El gesto de postrarse es realizado por un personaje en dirección a otro de condición superior. Puede expresar súplica, adoración, petición de perdón, petición de favor, rendición, obediencia etc. La realización de este gesto, por tanto, implica que aquella figura que lo ejecuta se encuentra en una situación desfavorecida, de manera que lleva a cabo este tipo de comportamientos ante aquella otra con potestad suficiente para prestarle su ayuda. 
b)

Conductas multimensajes

En segundo lugar, como señalábamos anteriormente, en la iconografía románica son frecuentes también las posturas que acogen varios sentidos, además de ser susceptibles de ser adoptadas por distintos personajes. Es decir, una conducta gestual puede significar varios conceptos, que pueden ser similares o bien diametralmente opuestos. Esta categoría sería muy similar a la que, en el campo de la antropología, Desmond Morris denomina gestos multimensajes, aquellos que tienen un número variado de significados totalmente distintos, en función del momento y el lugar ${ }^{12}$.

Como ejemplo representativo de este grupo de gestos, hemos escogido la representación de un personaje masculino, sedente o de pie, que se lleva una o las dos manos a la barba, aludiendo al gesto de mesársela. Dicha actitud asumió diversos significados en la iconografía románica. Por un lado, se trata de un gesto adoptado por personajes procedentes de categorías sociales elevadas, como reyes, jueces, altos dignatarios y sabios, tanto del ámbito sacro como laico. Se trata, en todos los casos, de una figura masculina que generalmente porta atributos de poder y que descansa su mano derecha o izquierda en una barba larga y poblada. En estos casos, la postura hace alusión a una actitud pensativa y reflexiva, anterior a la toma de la palabra o de una decisión. En el ámbito peninsular hispano, Herodes es el rey bíblico más representado de esta manera, inserto en la escena de la Matanza de los Inocentes, como podemos observar, por ejemplo, en la representación esculpida en la fachada de la iglesia de Santo Domingo de Soria (fig. 3) ${ }^{13}$.

\footnotetext{
${ }^{12}$ Cfr.: D. MORRIS, Op. cit., pp. 40-41.

13 Otros ejemplos muy similares en la plástica escultórica soriana son los esculpidos en uno de los capiteles del baldaquino de la epístola de la iglesia de San Juan de Duero y uno de los capiteles del interior de la catedral de Santa María en El Burgo de Osma.
} 


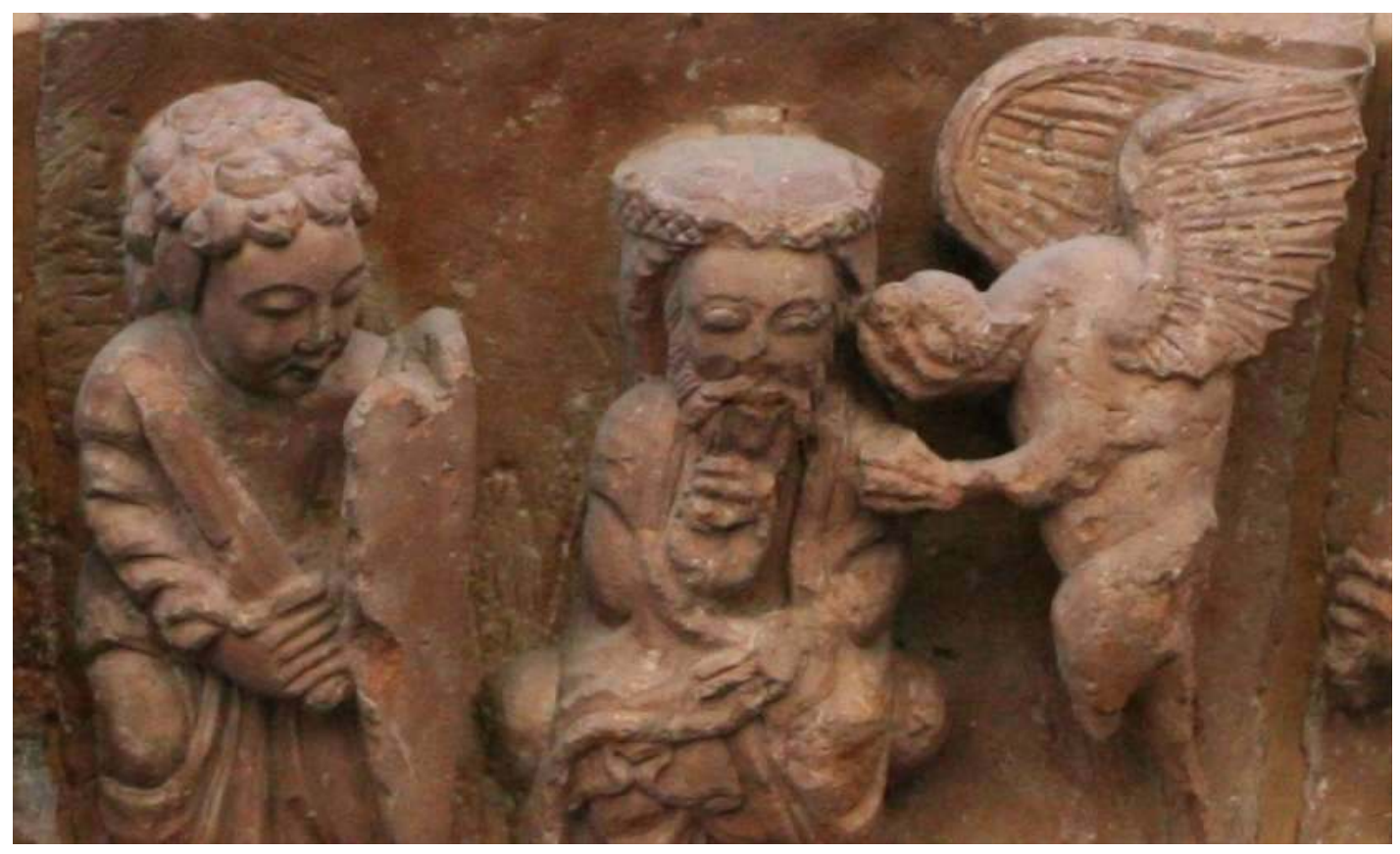

Fig. 3 Escena del asesoramiento del demonio a Herodes

Fachada occidental

Iglesia de Santo Domingo

Soria

Por otro lado, existe un segundo contexto iconográfico en el que encontramos la representación de una figura masculina, sedente, que se lleva una mano al mentón y se toca la barba. Se trata, generalmente, de personajes no insertos en ninguna escena narrativa, sino independientes y, frecuentemente, situados en los canecillos o ménsulas de las iglesias. Existen varias modalidades de esta actitud: en unos casos el personaje se lleva una sola mano a la barba al tiempo que la otra descansa sobre una rodilla o una pierna. En la Península Ibérica citamos como muestra los canecillos de las iglesias de San Esteban y San Miguel de Corullón (León), en los que se esculpió a un personaje con barba larga y estrecha (fig. 4) ${ }^{\mathbf{1 4}}$. En este contexto, la barba es símbolo de la dignidad y honor masculinos. Es indicador de la fuerza, la juventud y la virilidad, y está

${ }^{14}$ Sobre las representaciones en estas dos iglesias leonesas véase: M. C. COSMEN ALONSO, Dos iglesias románicas del Bierzo. San Miguel y San Esteban de Corullón, León, 1985, pp. 92 y 98 . Al analizar estos canecillos, esta autora relaciona el gesto de mesarse la barba con las ideas de lujuria y avaricia, por un lado, y de virilidad, por otro. 
relacionado con la honra masculina y la virilidad, de ahí que pueda adquirir también una connotación sexual.

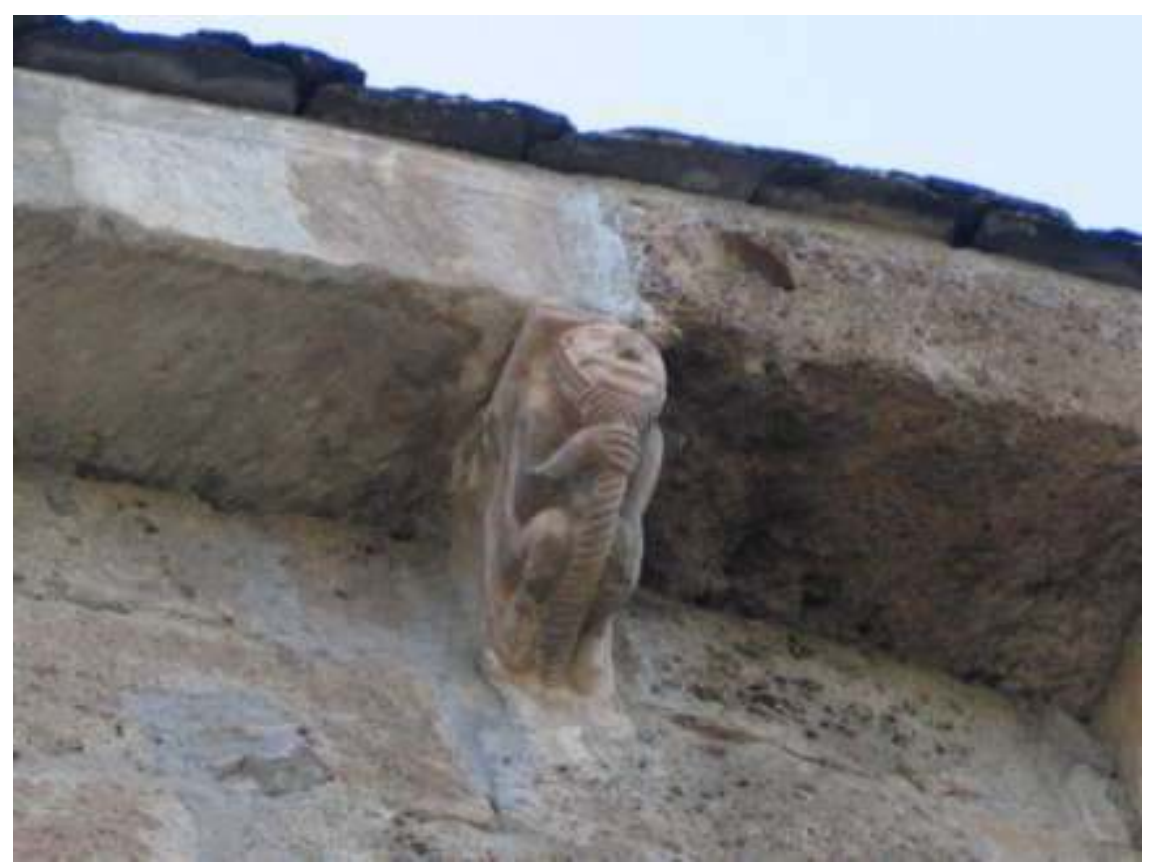

Fig. 4 Personaje mesándose la barba

Canecillo exterior

Iglesia de San Miguel

Corullón (León)

En tercer lugar, la representación de un personaje masculino que apoya una mano en su barba en la iconografía románica puede aludir al sentimiento de dolor y, en algunos casos, de ira. Se trata de la manifestación exterior de una afección interior: expresa una emoción violenta, un dolor interno muy intenso ante una situación desfavorable. En la plástica románica de los reinos hispanos se advierte su presencia entre los gestos de dolor que realizan los personajes que lamentan la muerte de doña Blanca de Navarra en el sepulcro que hemos citado anteriormente.

Por tanto, existen conductas gestuales en el arte románico que transmiten diversos significados y pueden ser adoptadas por múltiples personajes. Esta diversidad semántica ha tenido una consecuencia fundamental para el desarrollo de nuestro estudio. Nos referimos a la dificultad que supone, en muchos casos, el llegar a discernir el valor 
conceptual de los gestos en todas las imágenes románicas. Existen, numerosos ejemplos y casos dudosos en los que es realmente ardua la labor de descifrar el sentido acertado de un gesto en una escena determinada.

Como consecuencia de ello, a fin de descifrar el sentido concreto que el gesto tiene en una imagen o escena determinada, bien sea como espectadores o como investigadores, hay que tener en cuenta los demás componentes de la imagen, así como el propio contexto en el que ésta fue elaborada. Éstos son los que nos ofrecen la posibilidad de decantarnos por uno u otro de los significados posibles. Sin embargo, existen casos en los que las imágenes y, con ellas los gestos, se hallan desligadas del contexto o la escena primigenia para los que fueron creadas, lo que supone una intensificación del problema interpretativo. Ello nos ha dado pie para hablar del fenómeno de la descontextualización del gesto.

\section{c) La descontextualización del gesto y la pérdida de su carga semántica}

El fenómeno de la descontextualización del gesto puede deberse a dos motivos: uno casual y otro intencionado. La descontextualización casual comprende, fundamentalmente, el devenir del tiempo y los avatares que éste impone a toda obra artística. Debido a estos factores, actualmente existe un gran número de obras y, con ellas, los gestos, que han sufrido un deterioro importante o han sido trasladadas desde su ubicación original. Por ello, las atribuciones, interpretaciones e identificaciones que se pueden realizar son muy variadas.

Como muestra de este tipo de descontextualización del gesto podemos señalar la representación pictórica de una figura sedente aislada, procedente del conjunto de pintura mural que decoraba el interior de la iglesia de San Clemente de Taüll y que hoy se encuentra en la colección de arte románico del Museo Nacional de Arte de Cataluña. Es un personaje masculino sedente que apoya su cabeza ladeada en la mano cuyo brazo descansa, a su vez, en el muslo. Tanto la identificación de la figura como el significado 
de la actitud son verdaderamente difíciles de discernir, sobre todo si añadimos que el personaje no lleva ningún otro atributo o inscripción aclaratoria ${ }^{15}$.

El segundo motivo de descontextualización tiene un carácter más intencionado. En este sentido, es posible hallar dos tipos de situación, ambos asociados al papel del artífice de la obra. Por un lado, éste puede, deliberadamente, utilizar el gesto como un mero elemento decorativo. Por otro lado, podría ser que el artista malinterprete o desconozca la variedad de sentidos que puede adquirir un mismo gesto y que lo utilice sin tenerlos en cuenta, por puro desconocimiento o por hábito. De esta manera, la postura pierde todo su contenido y puede convertirse únicamente en un elemento ornamental.

\section{4. $\quad$ El origen de los gestos}

Siguiendo, en parte, las teorías antropológicas de Desmond Morris y analizando en conjunto el origen de los gestos que hallamos en la iconografía románica señalamos la existencia de tres tipos de conductas gestuales: las universales, las heredadas de civilizaciones anteriores y las que denominamos "regionales".

a)

\section{$\underline{\text { Conductas universales }}$}

En primer lugar, la existencia de conductas universales. Éstas no tienen origen en un lugar específico sino que han surgido en contextos espaciales y momentos históricos diferentes. Sin embargo, en todos los contextos en que las hallamos tienen el mismo significado ${ }^{16}$.

\footnotetext{
${ }^{15}$ La figura ha sido identificada como Jacob, el rico Epulón en el infierno, el santo Job o Efraín. El sentido del gesto ha sido relacionado con la plasmación gráfica del dolor interno. Sobre todas estas hipótesis, véase: M. PAGĖS I PARETAS, "Sobre la identificació d'una figura aïllada de l'absis de Sant Climent de Taüll”, Butlletí del Museu Nacional d'Art de Catalunya, 4 (2000), pp. 195-112; ID., "El valle de Boí. Historia y arte: sobre la construcción y decoración de sus iglesias románicas", Obres mestres del romànic. Escultures de la Vall de Boí, Barcelona, 2004, pp. 97-99, especialmente p. 98.

${ }^{16}$ En los campos de la antropología y de la semiótica, se denominan gestos universales a aquellos que no tienen origen en un lugar específico pero que en todos los contextos tienen el mismo significado. Sería el caso de los gestos de carácter mímico, es decir, de las conductas que imitan acciones, como el poner la mano delante de la boca para indicar hambre. Es el caso también de los gestos que expresan las muestras de afecto y las emociones. Sobre esto véase: P. EKMAN y W. V. FRIESEN, "The Repertoire of Nonverbal Behaviour: Categories, Origins, Usage and Coding", Semiotica, 1 (1969), pp. 49-98.
} 
Sería el caso de la genuflexión y la postración. Ambas posturas aparecen en civilizaciones y culturas alejadas desde el punto de vista temporal y espacial pero siempre con un mismo sentido, el de la adoración y la veneración. Podemos citar, por ejemplo, su presencia en la pintura prehispánica de Sudamérica. Así, en el cuarto 12 del palacio de Tetitla, en Teotihuacán, hallamos la representación de un hombre-jaguar arrodillado, con una de sus piernas flexionadas y la otra apoyada en el suelo, en actitud de reverencia ${ }^{17}$. Por lo que se refiere a la cuenca mediterránea, se trata de actitudes presentes prácticamente en todas las civilizaciones antiguas del Mediterráneo.

b)

\section{$\underline{\text { Conductas heredadas de civilizaciones anteriores }}$}

En segundo lugar, el grueso más significativo de las actitudes que encontramos en la iconografía románica nació, desde el punto de vista plástico, en culturas o civilizaciones anteriores y esas actitudes fueron asimiladas por el arte medieval. Esta categoría gestual podríamos relacionarla, en cierta medida, con lo que Desmond Morris denomina los "relic gestures", es decir, aquellos gestos que han sobrevivido una vez que la cultura que los gestó ha desaparecido ${ }^{18}$.

Como decimos, la mayor parte de las posturas que hallamos en las manifestaciones artísticas del período románico nacieron en culturas anteriores. Más concretamente, ello aconteció en cuatro de las grandes civilizaciones que estuvieron asentadas en el entorno de la cuenca mediterránea en el mundo antiguo: Egipto, Mesopotamia, Grecia y Roma. En este sentido, para nuestro análisis de los gestos en el arte románico, resulta de gran interés no sólo investigar en qué lugar o cultura surgió cada gesto, sino, además, cómo éste se expandió y logró alcanzar las creaciones artísticas románicas. Esto nos lleva, en la mayoría de las ocasiones, a analizar la circulación y transmisión de los gestos a lo largo de los períodos históricos antiguo y medieval, aunque hemos de señalar que resulta muy complejo explicar este tipo de procesos e influencias desde culturas tan alejadas tanto temporal como geográficamente respecto al arte románico de los reinos hispanos.

\footnotetext{
${ }^{17}$ Véase B. DE LA FUENTE (coord.), Pintura mural prehispánica, Barcelona, 1999, p. 55, fig. 29, foto 20. Agradezco a M. T. López de Guereño su amable ayuda en este aspecto.

${ }^{18}$ Cfr.: D. MORRIS, P. COLLETT, P. MARSH y M. O'SHAUGHNESSY, Gestures. Their Origins and Distribution, Nueva York, 1979, p. 263.
} 
Aún así, creemos que el arte románico pudo haber recibido la herencia del lenguaje gestual del mundo antiguo a través de varias vías fundamentales: por un lado, la sociedad y las creaciones altomedievales, entre las que sobresale el arte carolingio; por otro lado, las civilizaciones musulmana y bizantina, herederas del arte grecorromano, fueron también dos vías de transmisión fundamentales para la recepción de aspectos del arte antiguo en el arte medieval occidental.

En el caso concreto de la Península Ibérica, el arte románico, con todas sus características e influencias, penetró, en parte, gracias a las diversas rutas del Camino de Santiago. En este sentido, consideramos que debieron de tener una gran importancia los libros y plantillas de modelos que artistas y talleres giróvagos necesitaban con frecuencia como apoyo y soporte formal e iconográfico de su trabajo ${ }^{19}$.

En cuanto a las particularidades hispanas respecto al origen de los gestos, hemos de llamar la atención sobre el hecho de que, en suelo hispano, el arte románico de otras regiones europeas se vio enriquecido por varios aspectos fundamentales. Por un lado la propia tradición hispana altomedieval, en la que el arte visigodo, las manifestaciones del arte asturiano y la miniatura de los manuscritos de los Beatos son los puntales más importantes para el estudio de los gestos. Por otro lado, las creaciones artísticas de la civilización islámica, instalada en los territorios del sur de la Península, fue también de extraordinaria importancia. El arte musulmán, al igual que el bizantino, recibió una fuerte impronta de la cultura y el arte antiguos. A través de él, la plástica románica de los reinos hispanos consiguió asumir la utilización formal e iconográfica de varios de los gestos que hemos analizado.

\footnotetext{
${ }^{19}$ Durante todo el período medieval, parece claro que los artistas se ayudaron de algún tipo de hojas o plantillas de modelos de las que copiaban figuras y escenas de obras que veían, con el objetivo de utilizarlas después en obras suyas posteriores. Debido a que en época románica los artistas viajaban continuamente para encontrar trabajos y encargos artísticos nuevos, podemos suponer que la circulación de modelos y, con ellos, de gestos, fue fácil y relativamente rápida. En la Península Ibérica, además, hemos de tener en cuenta el papel desempeñado por el Camino de Santiago. Por las diferentes vías que se dirigían al extremo occidental de la Península circularon una gran cantidad de peregrinos y también de artistas para decorar los múltiples edificios que se construyeron. Éstos llevarían con ellos plantillas y modelos como apoyo gráfico a su trabajo. Aun así, hemos de señalar la inexistencia, hasta este momento, de hallazgos de libros de modelos en los territorios peninsulares. No ocurre así en otras áreas geográficas europeas, donde sí consta la existencia de varios "model books". Puede consultarse una recopilación en el estudio de R. W. SCHELLER, Exemplum: model-book drawings and the practice of artistic transmission in the Middle Ages (ca. 900 - 1470), Amsterdam, 1994.
} 
La tercera y última de las categorías que señalamos en relación con el origen de los gestos presentes en el arte románico podríamos denominarla "regional", es decir, nos encontramos con posturas que surgieron ex novo en la plástica románica y no fueron heredadas de manifestaciones artísticas ni anteriores ni coetáneas. Son muy pocas las actitudes susceptibles de ser incluidas en este grupo y creemos que su surgimiento en la iconografía románica tal vez recibiera la influencia del contexto cultural coetáneo. Los sermones, dramas litúrgicos y otro tipo de manifestaciones quizás tuvieron especial repercusión en el surgimiento de nuevas fórmulas gestuales. Además, podemos considerarlos como conductas cuyo surgimiento en la plástica románica supuso el punto de partida para un desarrollo iconográfico en el arte gótico.

Puede que el ejemplo más destacado de este tipo de gestos sea el de llevarse la mano a la garganta en la escena del pecado original ${ }^{20}$. Por lo que se refiere a los reinos hispanos, uno de los primeros ejemplos en los que lo hallamos es en las pinturas procedentes de la ermita segoviana de Santa Cruz de Maderuelo, del primer tercio del siglo XII ${ }^{21}$. A partir de mediados de esta centuria pero, sobre todo, en las últimas décadas y principios del siglo XIII, se produjo un intenso desarrollo de este gesto en el tema iconográfico que estamos analizando. Lo encontramos en todo tipo de soportes y en todas las regiones peninsulares. Señalamos como ejemplos altamente significativos, su presencia en la

\footnotetext{
${ }^{20}$ En ámbito europeo, destaca su representación en la región borgoñona, donde aparece en el exterior de las iglesias de Anzy-le-Duc, Neuilly-en-Donjon, Loupiac, Montpezat y Sainte Marie de Moirax.

${ }^{21}$ En el muro occidental de esta ermita se representaron dos escenas del Génesis: la creación de Adán y el pecado original. En la escena situada a la izquierda del espectador, la composición se ordena a partir del árbol del bien y del mal, situado en el centro. A un lado, y siguiendo la adaptación al marco curvo del muro, Eva toma el fruto prohibido de la boca de la serpiente y se tapa los genitales con una hoja, mientras que, al otro lado, Adán se lleva una mano a la garganta y utiliza también una hoja para taparse con la otra mano. El tipo de composición presente en Maderuelo, en el que Adán y Eva se hallan simétricamente colocados a un lado y otro del árbol del bien y del mal, alrededor del cual se encuentra enroscada la serpiente, remite al mundo paleocristiano. Como ha señalado S. Silva, en la Península Ibérica esta fórmula iconográfica se conoció relativamente pronto, gracias a un grupo de sarcófagos que fueron traídos de Roma en el siglo IV. La diferencia entre las pinturas de Maderuelo y todos los ejemplos paleocristianos estriba en que, en estos últimos, el gesto que estamos analizando no aparece. Sobre este ejemplo, véase: L. GRAU LOBO, La pintura románica en Castilla y León, Valladolid, 1996, pp. 128-139 y S. SILVA y VERÁSTEGUI, Iconografía del siglo X en el reino de Pamplona-Nájera, Pamplona, 1984, pp. 167-168.
} 
Biblia de Burgos o de Cardeña, de hacia $1175^{22}$ y en una Biblia procedente del fondo del monasterio de Santa Cruz de Coimbra, el códice conocido como Santa Cruz $1^{23}$.

${ }^{22}$ Burgos, Biblioteca Pública del Estado, fol. 12v. En la zona superior de un folio dedicado a ilustrar el ciclo de la caída, expulsión del Paraíso y vida fuera de éste, el miniaturista empleó un modelo iconográfico muy semejante al que hemos descrito de la ermita de Maderuelo. El árbol está situado en el centro. A su izquierda Eva coge el fruto de la boca de la serpiente mientras se tapa con su mano izquierda, al tiempo que Adán se lleva una mano al cuello y se cubre también con la siniestra. Aunque ambas obras son de estética y cronología completamente diferentes, nos parece que el paralelo desde el punto de vista iconográfico es notable. J. Yarza cree que el miniaturista que trabajó en la zona superior de este folio debía de conocer la miniatura inglesa, especialmente el entorno de Winchester, y que, además, tal vez fuera el mismo que participó en el Beato de San Pedro de Cardeña. Cfr.: J. YARZA LUACES, "Biblia de Cardeña", De Limoges a Silos, Madrid, 2001, pp. 280-281; ID., "Las miniaturas de la Biblia de Burgos", Archivo Español de Arte, n. 42, vol. 166 (1969), pp. 185-204.

En la región burgalesa, este gesto fue especialmente frecuente en las últimas décadas del siglo XII; citamos los ejemplos escultóricos de Butrera, Los Ausines, Riocavado de la Sierra, San Pantaleón de Losa y Siones.

${ }^{23}$ Porto, Biblioteca Publica Municipal, Ms. 32, fol. 2v, inicial I. En este folio se miniaron tres medallones con escenas del ciclo de la creación, pecado original y expulsión del paraíso. El segundo de estos momentos, que ocupa el medallón central, presenta una composición parecida a los ejemplos que hemos señalado, si bien con algunas diferencias destacables: el árbol está situado en el medio, con Eva a la izquierda; ella extiende el brazo para coger el fruto prohibido mientras se lleva el otro brazo hacia la boca para comérselo. Adán, a la derecha, tiene el fruto en una de sus manos y se lleva la otra a la garganta. Ninguno de los dos se tapa los genitales, al contrario que en otros casos. En esta escena se están representando simultáneamente dos momentos cronológicamente diferentes. Eva con una mano toma el fruto y con la otra ya se lo lleva a la boca, mientras que Adán todavía no lo ha comido pero ya acerca la mano a su cuello.

Esta Biblia fue fechada por W. Cahn en el segundo cuarto del siglo XII. Cfr.: W. CAHN, La Bible romane, Fribourg, 1982, p. 293. Sin embargo recientemente, A. Miranda, aunque con alguna duda, la fecha en la segunda mitad de esa misma centuria y, además, señala que existen ciertas similitudes iconográficas entre esta obra y la Biblia de Burgos. Véase: M. A. MIRANDA, "Iluminura românica em Portugal", La miniatura medieval en la Península Ibérica (ed. Joaquín Yarza Luaces), Murcia, 2007, p. 393. 


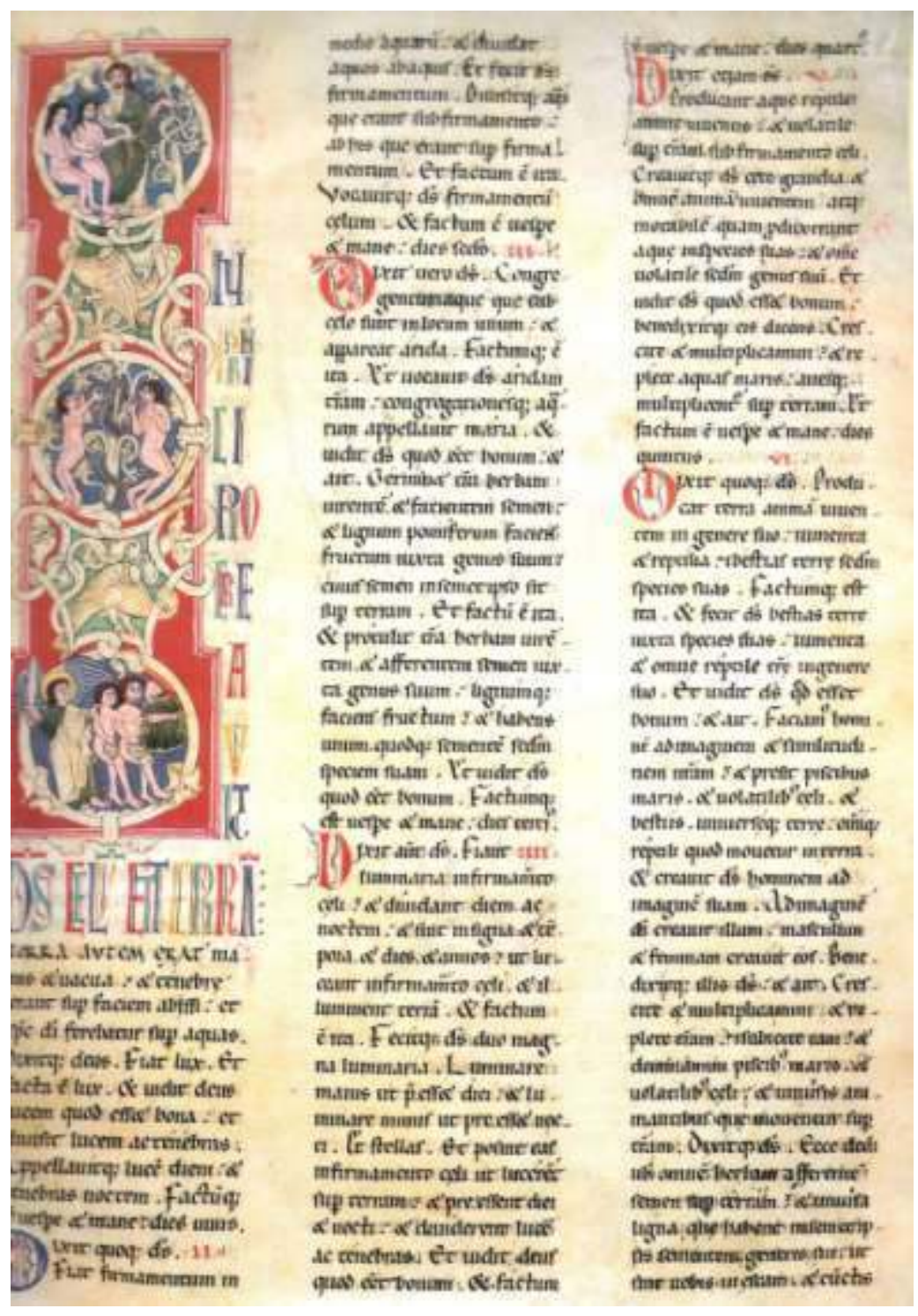

Fig. 5 Escena del Pecado Original

Biblia procedente del monasterio de Santa Cruz de Coimbra Porto, Biblioteca Pública Municipal, Ms. 32, fol. 2v, inicial I

En cuanto al significado de este gesto en la plástica románica se han apuntado varias hipótesis. Una de ellas alude a una cuestión natural: la manzana se habría atascado al llegar a la garganta y de ahí que Adán o Eva se lleven la mano al cuello, como consecuencia del dolor físico que les causa la situación. Otra de las teorías apuntadas también supone que ambos personajes se sujetan el cuello con la mano debido al dolor que sienten, pero en este caso sería un dolor interno, una muestra de pesar por haber comido el fruto prohibido y desobedecido el mandato divino. Existe una tercera 
posibilidad, que unifica ambos sentidos: se produce un atascamiento del fruto en la garganta, que alude simbólicamente al atragantamiento moral que sufren los primeros padres al darse cuenta del pecado cometido. Por último, se ha señalado también que este gesto constituye el tema iconográfico conocido como "el arrepentimiento de Adán”, el momento en el que éste se arrepiente del pecado que ha cometido e intenta, desesperadamente, no tragar el fruto antes de que sea demasiado tarde. La propia etimología del término garganta en latín, gula, se asimilaba asimismo al pecado de la gula y muchos autores como san Ambrosio, san Gregorio el Grande, Pedro Lombardo y Ruperto de Deutz propusieron que el pecado cometido por Adán en el paraíso había sido el de la glotonería, la temptatio gulae ${ }^{24}$.

Independientemente de la verosimilitud de estas teorías e hipótesis, lo que sí está claro es que este gesto no responde al texto bíblico. Además, es una postura completamente ausente en las imágenes que ilustran este pasaje desde época paleocristiana. En la Alta Edad Media, no aparece en las grandes Biblias carolingias del siglo IX, cuyas ilustraciones a toda página recogen varios momentos de la historia de los primeros padres $^{25}$. Tampoco lo hallamos en los grandes conjuntos románicos de pintura mural del siglo XI en los que se incluyó el ciclo del Génesis ${ }^{26}$. Por lo que se refiere

\footnotetext{
${ }^{24}$ Sobre las diferentes teorías en cuanto al significado de este gesto, véase: K. AMBROSE, "A visual pun at Vézelay: gesture and meaning on a capital representing the Fall of Man”, Traditio, 60 (2000), p. 111 y n. 24; E. FERNÁNDEZ GONZÁLEZ, "Lectura iconográfica del <pecado original> a través de la escultura románica de Villaviciosa", Studium Ovetense, VI-VII (1978-1979), p. 161; M. MELERO MONEO, "Aspectos iconográficos del Claustro de San Juan de la Peña: reconstrucción del programa de Caída y Redención", La cabecera de la Catedral calceatense y el Tardorrománico hispano. Actas del Simposio en Santo Domingo de la Calzada, 29 al 31 de enero de 1998, s. 1. 2000, p. 292, n. 9; L. RÉAU, Iconografía del arte cristiano. Iconografía de la Biblia. Antiguo Testamento, t. 1, vol. 1, Barcelona, 1996, p. 108; M. SÁENZ RODRÍGUEZ, "La iconografía de Adán y Eva en la escultura monumental del arte románico en La Rioja", Berceo, 126 (1994), p. 24 y J. YARZA LUACES, "De 'Casadas, estad sujetas a vuestros maridos, como conviene en el Señor' a 'Señora, soy vuestro vasallo, por juramento y compromiso"”, Formas artísticas de lo imaginario, Barcelona, 1987, p. 237.

${ }^{25}$ Las cuatro grandes Biblias carolingias que se conservan con escenas del Génesis son: la Biblia de Bamberg, Bamberg, Staatliche Bibliothek, Msc. Bibl. I (A.I.5), fol, 7v; la Biblia de Moutier-Grandval, Londres, British Library, Add. 10546, fol. 5v; la Biblia de Vivian o de Carlos el Calvo, Paris, Bibliothèque nationale de France, lat. I, fol. 10v; y la Biblia de San Pablo Extramuros, Roma, San Pablo Extramuros, fol. $7 \mathrm{v}$.

${ }^{26}$ Citamos como ejemplos las pinturas de Saint-Savin-sur-Gartempe, el ciclo más corto de ChateauGontier y el conjunto de la iglesia aragonesa de los santos Julián y Basilisa de Bagüés, obras en las que tampoco vemos la representación de esta postura. Otro tanto ocurre con los manuscritos anglosajones de esta misma centuria, como en el manuscrito Junius XI y en el Cotton Claudius IV, y la misma situación se repite en territorio italiano, donde tampoco encontramos tal postura, por ejemplo, en la Biblia de Todi, de esta misma época. Si nos trasladamos al ámbito bizantino, es significativa su ausencia en las miniaturas de los Octateucos conservados, sobre todo teniendo en cuenta que, en estos manuscritos, las miniaturas que ilustran este ciclo del Génesis son muy abundantes. Aun así, el momento iconográfico que nos
} 
específicamente a la Península Ibérica, no conocemos tampoco esta actitud en ninguno de los códices altomedievales conservados, manuscritos en los que, por otro lado, es muy frecuente la presencia de esta iconografía ${ }^{27}$. En la mayor parte de las obras, el gesto que expresa el sentimiento de Adán y Eva al darse cuenta del pecado cometido es el de llevarse la mano a la mejilla. Esta actitud, al contrario que la de sujetarse el cuello, sí es posible hallarla desde el siglo $\mathrm{X}$ en adelante, convirtiéndose en la disposición más frecuentemente utilizada por los artistas a la hora de plasmar el sufrimiento y el dolor de los primeros padres ${ }^{28}$.

La hipótesis que planteamos para el surgimiento y desarrollo de esta postura en un momento en el que la iconografía y las formas románicas estaban ya plenamente asentadas, es que sea una contaminación de los dramas litúrgicos ${ }^{29}$. Se constata la presencia de este tipo de obras en el marco peninsular ibérico desde finales del siglo XI en adelante aunque, hasta el momento, no se ha descubierto ninguna dedicada al ciclo del Génesis. En cambio, en ámbito europeo sí que se conservan, como es el caso del conocido como Jeu d'Adam u Ordo Representationis Adae, procedente de Tours y datado a mediados del siglo XII. En él se estipula claramente que los gestos realizados por los actores deberían ir acordes con el discurso y, además, la tentación y el pecado

interesa es resuelto mediante una composición en la que el árbol del bien y del mal se encuentra en el centro y a cada lado, como ocurre desde época paleocristiana, se colocan simétricamente Adán y Eva. Esta última toma el fruto prohibido del árbol y se lo acerca a Adán que se lo lleva a la boca.

${ }^{27}$ Nos referimos, principalmente, a los siguientes códices: las Biblias catalanas de Ripoll y Roda (Roma, Biblioteca Apostolica Vaticana, Vat. Lat. 5729, fol. 6r y París, Bibliothèque nationale de France, Lat. 6, fol. 6r); la Biblia de León del 960 (León, Archivo Capitular de la Real Colegiata de San Isidoro, Ms. 2, fol.15v); los códices conciliares Albeldense y Emilianense (El Escorial, Biblioteca del Real Monasterio de San Lorenzo, Ms. d. I. 2, fol. 17) y El Escorial, Biblioteca del Real Monasterio de San Lorenzo, Ms. d. I. I, fol. 14v) o los beatos en los que se incluye también la representación de las figuras de Adán y Eva, como en el Beato de Facundo (Madrid, Biblioteca Nacional, Ms. Vitrina 14-2, fols. 10v y 64); o en el Beato de San Millán (Madrid, Real Academia de la Historia, Cod. 33, fol. 18r).

${ }^{28}$ La iconografía de la expulsión del paraíso y el consiguiente dolor y sufrimiento de Adán y Eva han sido frecuentemente comparados con otro tema iconográfico, el de los condenados al infierno en el Juicio Final. En ambos casos, el dolor se plasma, entre otras maneras, con el gesto de llevarse la mano a la mejilla. Sobre todo ello, véase: M. BARASCH, Gestures of Despair in Medieval and Early Reinassance, Nueva York, University Press, 1976, pp. 12-17; y A. MIGUÉLEZ CAVERO, Actitudes gestuales en la iconografía del románico peninsular hispano, León, 2007, pp. 105-107.

${ }^{29}$ M. Barasch también establece una conexión entre varios gestos de carácter violento presentes en el tema iconográfico de la expulsión del paraíso y su descripción en los dramas litúrgicos. La actitud mencionada en este apartado es calificada por este investigador como una imagen de auto-estrangulación. Cfr.: M. BARASCH, Op. cit., p. 17. 
son los dos momentos en los que se hace mayor hincapie ${ }^{30}$. La razón principal para establecer un nexo de unión entre el gesto de llevarse la mano al cuello al tragar la manzana y este tipo de obras es que se trata de una postura muy natural $\mathrm{y}$, al mismo tiempo, muy expresiva. Teniendo en cuenta los objetivos que acabamos de señalar con los que surgieron los dramas litúrgicos, creemos que es factible que los actores clérigos comenzaran a realizar este gesto para mostrar simbólicamente el pesar y el dolor de los primeros padres al darse cuenta del pecado cometido y que, progresivamente, fuera trasladado al plano artístico ${ }^{31}$. Este tipo de actitudes y posturas, que formaban parte del lenguaje gestual de los monjes, podrían haber comenzado a ser utilizadas también en las representaciones rituales, es decir, en lo que hoy denominamos los dramas litúrgicos y que de ahí fueron traspasadas al campo artístico.

$* * *$

Éstas son las aportaciones que podemos señalar en relación con el estudio realizado sobre los gestos y la gestualidad en el arte románico de los reinos hispanos. Todas ellas esperamos poder analizarlas en mayor profundidad y ampliarlas en próximos trabajos; continuando así con una línea de investigación que pretende ser partícipe de los estudios de carácter interdisciplinar relacionados con la civilización medieval.

\footnotetext{
${ }^{30}$ K. AMBROSE, Op.cit., pp. 115-116. Este drama era representado en el exterior de la iglesia, donde se colocaba una plataforma. Cfr.: D. H. OGDEN, "Gesture and Characterization in Liturgical Drama", Gesture in Medieval Drama and Art (edited by Clifford Davidson), Kalamazoo, 2001, p. 33.

${ }^{31}$ Algo similar ha planteado K. Ambrose tras analizar un capitel de la nave de Vézelay en el que se representa el pecado original. En este caso, Adán se lleva una mano al pecho en vez de a la garganta, actitud muy parecida a la que aparece en otro capitel procedente de Cluny y hoy conservado en el Musée Farinier de esta abadía. Las dos escenas fueron probablemente realizadas por un mismo taller escultórico y para K. Ambrose, ambas variantes de este gesto, tanto la de llevarse la mano al pecho como a la garganta podrían ser la plasmación gráfica de gestos que eran realizados por los monjes en el interior de estas abadías. Además propone que se trataría de una especie de "juegos visuales", de manera que en el caso de la mano en la garganta se establecería un paralelismo entre gola y gula, y en el de la mano en el pecho sería entre pectus y peccatum. Cfr.: K. AMBROSE, Op. cit., pp. 110-112. Sobre la presencia de este gesto en los dramas litúrgicos veáse también: E. LOMMATZSCH, "Trauer und Schmerz in der altfranzösischen Literatur”, Zeitschrift für Romanische Philologie, XLIII (1923), pp. 20-67, especialmente p. 53.
} 


\section{REFERÊNCIAS BIBLIOGRÁFICAS}

AMBROSE, Kirk, "A visual pun at Vézelay: gesture and meaning on a capital representing the Fall of Man”, Traditio, 60 (2000), p. 105-123. ISSN 0362-1529.

ARCO, Ricardo Del, Sepulcros de la Casa Real de Castilla, Madrid: Consejo Superior de Investigaciones Científicas, 1954. 450 p.

BANGO TORVISO, Isidro Gonzalo, "El ámbito de la muerte”, in: BANGO TORVISO, Isidro Gonzalo (Dir.), Monjes y Monasterios. El Císter en el Medievo de Castilla y León, Valladolid: Junta de Castilla y León, 1998. ISBN: 8478467858. p. 317-328.

BARASCH, Moshe, Gestures of Despair in Medieval and Early Reinassance, New York: New York University Press, 1976. ISBN 0814710069. 162 p.

CAHN, Walter, La Bible romane. Chefs-d'oeuvre de l'enluminure, Fribourg: Office du Livre, 1982. ISBN 2719101605. 304 p.

COSMEN ALONSO, $\mathrm{M}^{\mathrm{a}}$ Concepción, Dos iglesias románicas del Bierzo. San Miguel y San Esteban de Corullón, León: Institución "Fray Bernardino de Sahagún", 1985. ISBN 84-00-06109-8. 186p.

DÍAZ-CORRALEJO, Violeta, Los gestos en la literatura medieval, Madrid: Editorial Gredos, 2004. 277 p. ISBN 84-249-2700-1.

EKMAN, Paul y FRIESEN, Wallace V., "The Repertoire of Nonverbal Behaviour: Categories, Origins, Usage and Coding", Semiotica, 1 (1969) p. 49-98. ISSN: 00371998.

FERNÁNDEZ GONZÁLEZ, Etelvina, 'Lectura iconográfica del 'pecado original' a través de la escultura románica de Villaviciosa", Studium Ovetense: Revista del Instituto Superior de Estudios Teológicos del Seminario Metropolitano de Oviedo, VI-VII (19781979). ISSN 0211-0741. p. 153-164.

FERREIRA DE ALMEIDA, Carlos Alberto, História da arte em Portugal. O Românico, Lisboa: Ed. Presença, 2001. 190 p. ISBN 97-223-2827-1.

FINOL, José Enrique, “Cuerpo y rito: la estructura del gesto en ceremonias públicas”, Los Gestos. Sentidos y prácticas. DeSignis, 3 (2002), p. 81-90. ISSN 15194223. 
FRUGONI, Chiara, "La grammatica dei gesti. Qualche riflessione", in: Atti delle LII Settimane di Studio della Fondazione Centro Italiano di Studi sull'alto Medioevo: Comunicare e significare nell'alto Medioevo, 15-20 aprile 2004, 2 vols., Spoleto: Presso la sede della Fondazione, 2005. ISBN 88-7988-051-9. Vol. II, p. 895-937.

FUENTE, Beatriz de la (coord.), Pintura mural prehispánica, Barcelona: Lunwerg, 1999. 272 p. ISBN 84-7782-608-0.

GÓMEZ BARCENA, María Jesús, Escultura gótica funeraria en Burgos, Burgos: Excma. Diputación Provincial de Burgos, 1988. 261 p. ISBN: 8486841011.

GÓMEZ-MORENO, Manuel, El Panteón de Las Huelgas de Burgos, Madrid: Consejo Superior de Investigaciones Científicas, 1946. 113 p.

GRAU LOBO, Luis, La pintura románica en Castilla y León, Valladolid: Junta de Castilla y León, 1996. 222 p. ISBN: 84-7846-540-5

GUIANCE, Ariel, Los discursos sobre la muerte en la Castilla Medieval (siglos VIIXV), Valladolid: Junta de Castilla y León, 1998, 443 p. ISBN 84-7846-780-7.

HERNANDO GARRIDO, José Luis, "Santa María la Real de Las Huelgas", Enciclopedia del Románico en Castilla y León. Burgos. Volumen II, Aguilar de Campoo: Fundación Santa María la Real, 2002. ISBN 84-89483-22-1. p. 794-803.

HERRERO SANZ, María Jesús, "Los sepulcros del Panteón Real de Las Huelgas", Reales Sitios, XXVIII, nº 105 (1990). ISSN 0486-0993. p. 21-30.

HOYO, Javier Del, "El epitafio versificado atribuido a la infanta Leonor", Actas del II Congreso Internacional de Epigrafía Medieval, 11-15 de septiembre de 2006 (en prensa).

KENDON, Adam, "Gesture", Annual Review of Anthropology, 26 (1997), ISSN 00846570. p. 109-128.

LE GOFF, Jacques y TRUONG, Nicolas, Une histoire du corps au Moyen Âge, París : Liana Levi, 2003. ISBN 2867463238.

MELERO MONEO, María Luisa, "Aspectos iconográficos del Claustro de San Juan de la Peña: Reconstrucción del programa de Caída y Redención”, in: BANGO TORVISO, Isidro Gonzalo, ESPAÑOL BELTRÁN, Francesca, YARZA LUACES, Joaquín (eds.), La cabecera de la Catedral calceatense y el Tardorrománico hispano. Actas del 
Simposio en Santo Domingo de la Calzada, 29 al 31 de enero de 1998, Santo Domingo de la Calzada : Cabildo de la S.M.I. Catedral de Santo Domingo de la Calzada, 2000. ISBN 1902902149. p. 285-311.

MIGUÉLEZ CAVERO, Alicia, Actitudes gestuales en la iconografía del románico peninsular hispano, León: Universidad de León, Secretariado de Publicaciones, 2007. ISBN 9788497733649. 204 p.

ID., "Texto, imagen y música: el dolor ante la muerte del infante don Sancho en el Panteón Real de Las Huelgas", II Coloquio Internacional de Epigrafía Medieval, León 11-15 de septiembre de 2006 (en prensa).

MIRANDA, Maria Adelaide, "Iluminura românica em Portugal", in: YARZA LUACES, Joaquín (Ed.), La miniatura medieval en la Península Ibérica, Murcia: Nausícaä, 2007. ISBN 978-84-96114-88-3. p. 375-418.

MORRIS, Desmond, Manwatching A Field Guide to Human Behavior, New York : H. N. Abrams, 1977. 320 p. ISBN 0810913100.

MORRIS, Desmond, COLLETT, Peter, P. MARSH, Peter, Gestures. Their Origins and Distribution, New York: Stein and Day, 1979. ISBN: 0812826078. 296 p.

OGDEN, Dunbar H. "Gesture and Characterization in Liturgical Drama", in: DAVIDSON, Clifford (ed.), Gesture in Medieval Drama and Art, Kalamazoo: Medieval Institute Publications, Western Michigan University, 2001. ISBN 1580440282. p. 26-47.

PAGÈS I PARETAS, Montserrat, "Sobre la identificació d'una figura aïllada de l'absis de Sant Climent de Taüll”, Butlletí del Museu Nacional d'Art de Catalunya, 4 (2000), ISSN 1133-6455. pp. 105-112.

ID., "El valle de Boí. Historia y arte: sobre la construcción y decoración de sus iglesias románicas", in: Obres mestres del romànic. Escultures de la Vall de Boí, Barcelona: Museu Nacional d'Art de Catalunya; París: Réunion des musées nationaux, 2004. ISBN 8480431261. pp. 97-99.

PÉREZ CARMONA, José, Arquitectura y escultura románicas en la provincia de Burgos, Burgos: Facultad de Teología del Norte de España, 1974. 301 p. ISBN 8423952568 
POYATOS, Fernando, La comunicación no verbal, 3 vols., Madrid: Ediciones Istmo, 1994. ISBN 84-7090-279-2.

ID., "Gesture Inventories: Fieldwork Methodology and Problems", in: KENDON, Adam, Nonverbal Communication, Interaction and Gesture. Selections from Semiotics, The Hague: Mounton Publishers, 1981. ISBN 9027934894. p. 199-227.

RÉAU, Louis, Iconografía del arte cristiano. Iconografía de la Biblia. Antiguo Testamento, Barcelona: Ediciones del Serbal, 1996. ISBN 84-7628-159-5. 526 p.

RODRIGO ESTEVAN, María Luz, Testamentos medievales aragoneses. Ritos y actitudes ante la muerte (siglo XV), La Muela (Zaragoza): Ediciones 94, 2002. 301 p. ISBN $\underline{84-88921-32-2 .}$

SÁENZ RODRÍGUEZ, Minerva, "La iconografía de Adán y Eva en la escultura monumental del arte románico en La Rioja”, Berceo, 126 (1994), ISSN 0213-4292. p. 17-34.

SÁNCHEZ AMEIJEIRAS, Rocío, "Ecos de la Chanson de Roland en la iconografía del sepulcro de doña Blanca en Santa María la Real de Nájera”, Ephialte: Lecturas de Historia del Arte, 2 (1990), ISSN 0214-6444. p. 206-214.

SCHELLER, Robert W., Exemplum: model-book drawings and the practice of artistic transmission in the Middle Ages (ca. 900 - 1470), Amsterdam: Amsterdam University Press, 1994. ISBN: 9053561307. 434 p.

SCHMITT, Jean-Claude, "Gestus-gesticulatio: contribution à l'étude du vocabulaire latin médiéval des gestes", in : La lexicographie du latin médiéval et ses rapports avec les recherches actuelles sur la civilisation du Moyen Âge, París: Éd. du CNRS, 1981. ISBN 2-222-02649-0. p. 377-390.

ID., La raison des gestes dans l'Occident médiéval, Paris : Éditions Gallimard, 2003. 432 p. ISBN 2-07-071845-X.

SILVA y VERÁSTEGUI, Soledad, "La escultura funeraria en el románico español”, in: Hispania cristiana: Estudios en honor del prof. D. José Orlandis Rovira en su septuagésimo aniversario, Pamplona: Ediciones de la Universidad de Navarra, 1988. ISBN 84-313-1034-0. p. 323-350. 
ID., Iconografía del siglo X en el reino de Pamplona-Nájera, Pamplona: Diputación Foral de Navarra, 1984. 511 p. ISBN: 84-235-0632-0.

VALDEZ DEL ÁLAMO, Elizabeth, "Lament for a lost Queen: the sarcophagus of Doña Blanca in Nájera”, in: VALDEZ DEL ALAMO, Elizabeth y STAMATIS PENDERGAST, Carol, Memory and the Medieval Tomb, Cambridge: Ashgate Publishing, 2000. ISBN 978-0754600763. p. 43-79.

YARZA LUACES, Joaquín, "Biblia de Cardeña", in: De Limoges a Silos, Madrid: Sociedad Estatal para la Acción Cultural Exterior, 2001. ISBN 84-95146-95-9. p. 280281.

ID., "De 'Casadas, estad sujetas a vuestros maridos, como conviene en el Señor' a 'Señora, soy vuestro vasallo, por juramento y compromiso'”, in: YARZA LUACES, Joaquín, Formas artísticas de lo imaginario, Barcelona: Anthropos, 1987. ISBN 8476580355. 292 p.

ID., "Las miniaturas de la Biblia de Burgos", Archivo Español de Arte, n. 42, vol. 166 (1969), ISSN 0004-0428. p. 185-204.

\section{COMO CITAR ESTE ARTIGO}

Como citar este artigo: MIGUÉLEZ CAVERO, Alicia - "Aportaciones al estudio de la gestualidad en la iconografía románica hispana”. Medievalista [Em linha]. №8, (Julho de 2010). [Consultado dd.mm.aaaa]. Disponível em http://www2.fcsh.unl.pt/iem/medievalista/MEDIEVALISTA8lcavero8006.html. ISSN 1646-740X.

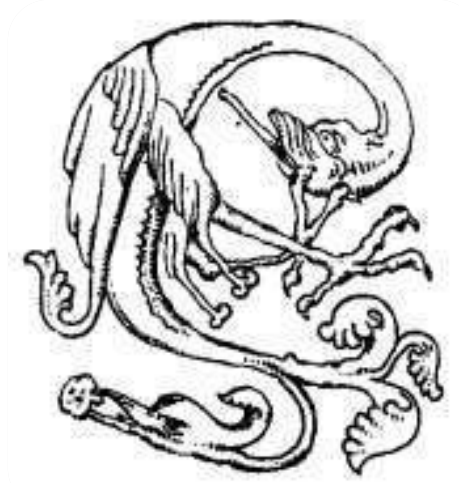

